EXEMPLARIa Classica

Journal of Classical Philology

18, 2014, pp. 155-163

ISSN 1699-3225

\title{
GOLDBERG AND BARSBY: TWO CAMBRIDGE COMMENTARIES ON TERENCE COMPARED
}

Sander M. Goldberg, Terence, Hecyra, Cambridge Greek and Latin Classics, Cambridge: Cambridge at the University Press, 2013. Pp. ix +223. ISBN 978-0-521-89692-4 (hardback), 978-0-521-72166-0 (paperback)

Prof. Goldberg offers a radically different sort of 'edition' cum commentary. He begins his preface (pp. vii-viii) with a potentially misleading rhetorical ploy. He quotes a 1972 essay by Jovan Hristić ${ }^{1}$ on post-Renaissance European literature to the effect that 'when we read drama, we treat it in the same way we would any other literary text intended for reading', and are wrong to do so, because 'the very act of reading a drama is directed toward a goal different from that of reading lyrics or novels. Drama is written to be played on a stage, and as a literary form it functions only if it offers the possibility of performance'.

He draws from this truism a sharp but false contrast between the script of Terence's Hecyra as the raw material of one or many circumstantially different performances, and the reading of a literary work such as Ovid's Tristia III: 'Terence's Hecyra was not ... a text in that sense. It was first a script created for a very different type of performance'. A footnote refers to five recent discussions of Roman reading, but without clarification, and without acknowledging the essential aurality of all Greek and Latin literary genres.

In fact, the ancients generally experienced poetry as if listening to a live broadcast on the radio. So Ovid's Tristia III, addressed to you, the lector, is not really so different from a dramatic script, because you are reading it aloud as a performer yourself, often before some sort of audience, small or grand. In the essay quoted, Hristić was of course taking it for granted that nowadays the act of reading is typically a silent solitary activity. Goldberg may inadvertently imply to his less experienced readers that the ancients were likewise given to silent reading of all their genres of literature other than drama; but as E. J. Kenney once put it the modern reader, who is accustomed to taking in literature through the eye rather than through the ear, cannot be too frequently reminded that nearly all the books discussed in this history were written to be listened to'

${ }^{1}$ 'On the Interpretation of Drama', New Literary History 3, 1972, 345-54.

${ }^{2}$ The Cambridge History of Classical Literature, (CHCL) vol. 2 Latin Literature, ed. 
Goldberg declares (p. vii): 'As the written remains of dramatic performance, the Hecyra invites different interpretive strategies from those designed for more familiar objects of academic attention. We must not only grasp what its characters say, but consider how they look, how they sound, and what they do. All that requires imagination, and while the results of that imaginative process may be less amenable to absolute demonstration than philologists might wish, ignoring questions of performance, refusing to frame hypotheses about how a scene was or could be played, certainly misrepresents the signifcance of the surviving text and the dramatic art to which it is a witness'. Ho-hum: who does not know that already?

II

Goldberg has published several literary studies on Terence ${ }^{3}$, but this is his first shot at a formal commentary. To understand his approach and aims, it is useful, though he does not mention it here, to refer to his review ${ }^{4}$ of J. Barsby's Eunuchus (1999) in the same Cambridge series as this much slimmer and cheaper Mother-in-Law 5 .

He praises Barsby's comprehensive and well-balanced handling of 'performance'(i.e., production), of grammar, of syntax, of the debatable moral tone of that play, and of the fragments of Menander's Eunouchos and Kolax behind it 'for those interested in pursuing the matter of Terence's originals' He dwells briefly on the way that Barsby deals with the substantive and pedagogical problems of Terence's prosody and metre, and on the question whether it matters anyway. Barsby's appendix on metre and scansion first introduces the metres in the traditional way with quantitatively variable binary feet of three or four time-units unpredictably deployed and with the usual nomenclature ${ }^{7}$ (290-3). He then (293-301) turns to the pre-classical oddities of Terence's prosody ${ }^{8}$. Goldberg explodes. 'Though traditional metrics ${ }^{9}$ describes everything, it explains nothing, merely bogging students

E. J. Kenney and W. V. Clausen, Cambridge 1982, 3.

${ }^{3}$ His interest goes back to The Making of Menander's Comedy, London 1980, followed inter alia by 'Scholarship on Terence and the Fragments of Roman Comedy', Classical World 75 1981, 77-115; Understanding Terence, Princeton 1986; 'Plautus on the Palatine', JRS 88 1998, 1-20, Constructing Literature in the Roman Republic: Poetry and its Reception, Cambridge 2005; 'Roman Comedy Gets Back to Basics', JRS 101, 2011, 206-221.

${ }^{4}$ Bryn Mawr Classical Review (BMCR) 1999. 06. 23.

${ }^{5}$ Barsby's Eunuchus has 336 pages, Goldberg's Hecyra only 223. Martin's Adelphoe has 259, Gratwick's Menaechmi 276, Christenson's Amphitruo 339, all in the same Cambridge series, so this is a radical difference.

${ }^{6}$ Goldberg is not among these: 'If what we really care about is a Roman Comedy, why should we pay more than token attention to the fact that it was based on a Greek one?', Hec. 9 .

${ }^{7}$ Senarii, septenarii, octonarii.

${ }^{8}$ Iambic shortening, synizesis, enclisis, apocope, prodelision, archaic long vowels, hiatus, prosodic hiatus, brevis in longo, Ritschl's and Hermann's Laws.

${ }^{9}$ He should have said 'prosody'. 
down in detail and leading them to wonder how Terence ever wrote a line without a German philologist to tell him how'. This rather distasteful outburst was at least not directed against Barsby, who immediately (pp. 301-4) identifies three of the fundamental flaws and false assumptions made in the traditional account which render it so clumsy and reductive.

Goldberg rather timidly commends Barsby for recognizing instead that the odd and even feet in these metres are not undifferentiated, but contrasted overall: the statistics show that they are realised in different complementary ways. The preferred and sometimes obligatory forms of quaternary measure in this versification are - - - ... A B c D... for iambic progression and -- - - B c D A... for trochaic, other permissible permutations (-- - - B C D A , etc., etc.) being variously conditional. This metrical analysis explains the relationship and point of those boring German philologists' observations. This new approach was devised by $\mathrm{me}^{10}$, and is now standard, at least in these Cambridge "greenand-yellow' editions of Plautus and Terence, including this Hecyra (p. 39), though Goldberg does not actually put it to work. The silence about all this in Europe remains deafening,

Barsby also takes from my editions of Menaechmi and Adelphoe the sublinear dots set in the text marking the phonetic point of onset of all the $\mathrm{B}$ and $\mathrm{D}$ metrical positions, that is the longa, doing so for the practical reasons that he gives on his p. 293 - they mark the onset of the long positions, whether in iambic or trochaic verse and thus facilitate the identification of the putative $^{11}$ ictus; they should also help with syllable division the recognition of elisions, and the division into feet' ${ }^{\prime 2}$. Goldberg does not like the look of these dots, thinks they make life too easy for the student (?!), and appears to have misinterpreted them anyway as ictus marks, which they are not. In this edition he does not adopt this way of helping the reader, and instead religiously preserves the mummified diacritics used by Lindsay in the $O C T$, which saves him the trouble of making any truly editorial decisions; as far scansion is concerned, it is a retrograde step back to the 1920's, for Lindsay's prosodical and phonetic theories are by no means all soundly based ${ }^{13}$.

\section{III}

Goldberg mostly follows the overall pattern set by Barsby, but with different emphases and always less comprehensively. His Introduction

${ }^{10}$ See $C H C L$ vol. 2, pp. 86-93; Terence, The Brothers, Warminster 1987, 276-83, 2nd ed., ibid. 1999, 209-37, and Plautus, Menaechmi, Cambridge 1993, 40-63, 248-60.

${ }^{11} \mathrm{My}$ only quibble with this is that Barsby puts the point about ictus first when it ought to come last, since ictus is at best epiphenomenal in this purely quantitative versification.

${ }^{12}$ BMCR 1999. 06. 23, second last paragraph.

${ }^{13}$ E.g. his notions of the readiness with which a final $-\underline{s}$ may be dropped before an initial consonant (Hec. 84, 98, 129, 168 etc.) and his often unwarranted preference for resolution over crasis or elision where vowels meet between words (Hec. 85, 197, 204, 210 etc.). 
includes the business of scansion, and at 47 pages it is much the same in volume as Barsby's; but Goldberg takes too much time in getting to the point. His introduction is divided into seven sections as follows: 1. Comedy at Rome, 2. The Career of Terence, 3. The Hecyra, 4. Language and Style, 5. Metre, 6. Donatus, 7. Transmission. The Latin script occupies pp. 4983, the commentary pp. 84-201. There is an appendix on the chronology of Philumena's pregnancy, pp. 203-4, and another on 'Greek analogues' comparing Hecyra with passages of Menander's Epitrepontes, pp. 205-6 . Lastly there is a bibliography (pp. 209-20) and an index of topics (pp. 221-3). content. I report on them in that order.

1. Comedy at Rome, pp. 1-10: First, a history of Roman Comedy before Terence (pp.1-4), emphasizing the improvisations and precarious circumstances of theatrical events funded by the aediles at Roman festivals, and introducing Terence's actor-manager Ambivius Turpio and Terence's regular piper Flaccus Claudi, 'F. a slave of Claudius'; Goldberg does not go into their respective social positions, the one apparently a full ciuis Romanus, the other a slave, nor does he explain that the troupes were all male, wore masks, and would often have to double or even split roles.

2. As for the audience (pp. 4-6), he decribes its boisterous social mix, and, rather irrelevantly in the immediate context, the occasional pantomimic ruptures of the glass wall between the characters on stage and the spectators in Plautus Poen. 17-20 and Aul.715-20. He proceeds (pp. 7-10) to a reductive and polemical survey of 19th-20th century approaches to Roman Comedy in general, asserting that the search for Greek originals through the Latin texts has had its day, that 'intertextuality' is now the thing, and recommending that the commentator should as a rule 'draw analogues and parallels from the Greek material without necessarily positing direct relationships as sources or targets of allusion. This can make the critic's task a little easier'. None of this will mean much to the neophyte.

3. The career of Terence, pp.10-14: Goldberg dismisses Suetonius' Vita Terenti as obviously unreliable, putting more faith in the didascaliae and what can be deduced from the prologues, which he assumes actually are the work of Terence himself ${ }^{14}$. Goldberg notes Terence's preference for Menander over other writers of New Comedy, the 'image' of himself projected in the prologues as a progressive young artist frustrated by reactionary seniors, and what Goldberg regards as modern critical misapprehensions about Terence's originality or lack of the same; and he asserts the overall Romanness of Terence's comedy, pointing to his ready recourse to the popular stock comic themes and situations of the older Roman theatre, e.g. the running slave routine.

\footnotetext{
${ }^{14} \mathrm{He}$ does not reckon with the possibility that they are the work of Ambivius Turpio, for the 'Asianic' rhetoric of these pieces is so unlike the generally unobtrusive 'Atticist' style of the plays. We cannot be sure either way.
} 
4. The Hecyra: Goldberg sceptically reviews (15-8) what the two prologues and the garbled accounts in the didascaliae actually tell us about the particular troubles encountered by the troupe in getting a fair hearing for the play at all, but rightly holds that they are plausible evidence in general for the potentially chaotic consequences of badly scheduled alternative entertainments in the open air at a Roman festival. Turning (at last!) to the play itself (pp. 18-25), he says 'Responses to Hecyra have proven especially problematic. Generations of critics, who come (sic) to the play more often as readers than as spectators, have debated whether Bacchis is generous or selfish, whether Pamphilus' moral culpability has limits, and whether Sostrata's abrupt disappearance is troubling by design, but no consensus has ever emerged. Even the most basic questions of interpretation remain contingent on too many possible stimuli and too many possible responses to establish any one set of answers as definitive. A more productive approach would be to replace the futile and reductive quest for a single meaning with the articulation of questions that open for exploration a full range of possible readings'. (More rhetoric!) 'A list of such questions for Hecyra could include the following...'.

The next five sections 3. 2. 1-3.2.5, pp. 19-25, pose and offer provisional answers to these questions, which baldly reported are as follows.

Q. How does the play's structure shape the audience's response? $\underline{\mathrm{A}}$. By suspense and keeping us guessing (pp. 19-20).

Q. How does Terence handle his stock characters and the exspectations they arouse? A. By defeating expectations - Parmeno the failed servus callidus (879-80), Sostrata not the stereotypical mother-in-law (277-8), Bacchis the bona meretrix (p. 20-1).

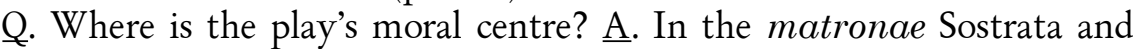
Myrrina p. 21-3).

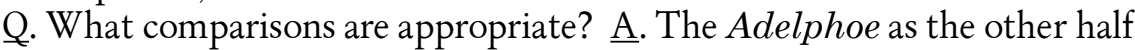
of a double bill in 160 B.C. (pp. 23-5).

This is a useful discussion, defining and focussing the main problems but only if you know the play already!

However, up to p. 19, Goldberg has said nothing at all about the action. The reader might reasonably expect to be informed about 'the plot' much sooner. Goldberg has in effect been writing a potted general history of the early Roman theatre, with roughly as much about Plautus as about Terence, interspersed with generalisations about right and wrong ways for the critic to approach the Roman comedians. In the commentary he is commendably concerned to connect with the undergraduate student who has little Older Latin and less Greek. Since there are, as Goldberg says himself (p. 1 n. 1), other excellent places where the novice may go for the historical side, why be so discursive? It is not as if Goldberg has any crucially new historical facts 
to impart. As for his views as a 'performance-critic' on issues of dramatic interpretation, these seem inappropriately placed, as they can make little sense to the novice who has not yet gone through the Latin, and does not even know the plot of play; they would have been better more discretely set in the notes in the commentary as and when appropriate.

It is, however, quite astonishing that the discussions of those questions (pp. 18-25) are composed on the assumption that the reader already knows the plot in some detail. This fault in presentation could have been simply remedied, e.g. by including the text of Sulpicius Apollinaris' periocha with a brief commentary, the earlier in the introduction the better; but for some odd reason neither Goldberg nor Barsby thought it worthwhile even to mention him.

\section{IV}

The remainder of the Introduction is devoted to observations on some more technical matters. The first three sub-sections of the discussion of 'Language and Style' (25-9), respectively on orthography, diction, and arrangement, are at once jejune and superfluous, because almost everything said here later is found repeated at the appropriate place in the notes of the commentary. The fourth, on 'aesthetic effects' (pp. 30-2) has no mention of Menander as the obvious model for Terence's tenuis oratio and scriptura leuis in Latin. Goldberg dwells on why this was unfamiliar and controversial at the time, but has too little on why Terence's purus sermo came to be so admired by Cicero's time and later; there is nothing about Terence's canonical place as Menander Latinus in the rhetorical syllabus of Imperial times alongside the Roman Homer, Virgil. Section 5 on Metre occupies 9 pages and is a direct abbreviation of of Barsby's corresponding appendix (14 pages). The contrast between the two accounts underlines the excellence and precision of Barsby's. Goldberg is clearly still not entirely at home with this subject ${ }^{15}$. Section 6 on Donatus and the omnium-gatherum commentary that goes under his name is surely kinder to him (or rather them) than fits the case. The two illustrative quotations on p. 42 involving Greek should have been translated. There is a well-informed summary of the descent of the MSS in section 7 on the text (pp. 43-7), but there is nothing at all about Terence's history in print since

${ }^{15}$ For instance, in defining brevis in longo (p.40) Goldberg states that it is 'a short vowel lengthened at the end of a colon'. No; it is a light final syllable $\underline{\mathrm{d}+}$, open or closed, occupying a long metrical place $\mathrm{D}$, as ...c $\underline{\mathrm{d}+/}$ for $\ldots . \underline{\mathrm{c} D /}$. This is commonplace in line-end and the mid-line break of long verse-forms, e.g. Hec. 243, 325, 531, 621, 830 and analogous positions (Hec. 621). We cannot know whether in delivery such a syllable would be 'stretched' or not. Goldberg is

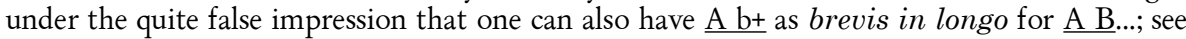
his dreadful note on Hec. lines 1-2 quoted below. The allusion to 'the two iambs of funambulo' in the note to line 4 is also prosodically, well, unfortunate. 
the Renaissance. ${ }^{16}$ Goldberg picks the MSS readings and side-transmission at Hec. 337 and 313 as 'to illustrate the nature of the editor's task', but this was disingenuous, because the reader is invited to conclude from these footling instances that in Terence textual criticism is in principle a pedantic waste of time, and that the modern vulgate versions are good enough. But what, for instance, about the text at lines 1-2? Goldberg doesn't even notice that there is a problem there concerning the scansion and the tex $\mathrm{t}^{17}$.

It comes as a particular rhetorical shock in the last paragraph of the Introduction (p. 46-7) that 'the approximation to Terence's original Hecyra that accompanies this commentary does nor represent a new critical edition and attentive readers will notice only a few significant departures from the Oxford text of Kauer and Lindsay ${ }^{18}$... Lindsay's diacritical aids to scansion are reproduced in hope of encouraging attention to metre ${ }^{19}$.

\section{$\mathrm{V}$}

On the face of it, then, Goldberg is simply doing the same as Barsby in his Eunuchus by making use of the OCT, but that is not at all the case. Barsby p. 31 states that 'This edition presents a plain text without the usual apparatus criticus ... where there are textual problems of major interest or importance for the understanding or interpretation of the play, these are discussed in the commentary and thr principal readings given ... the text in this edition is based on the information provided by the editions of KauerLindsay (1958) and Marouzeau'.

There is therefore actually a huge difference between Barsby, who really has edited the play ${ }^{20}$, and Goldberg, who has merely copied it.

In Hecyra the script is set on the page between a pair of inner margins three inches wide, flanked by a pair of outer magins 3.75 inches apart with metrical identifications $\underline{i a}^{6}, \underline{\operatorname{tr}}^{7}$ set at the outer left-hand margin and linenumbers set to the outer right. This works well and chastely for the senarii,

${ }^{16}$ His only allusion to a printed edition prior to the $O C T$ is to Bentley's (Cambridge, 1726) on p. 37. Goldberg does not list it in his bibliography; but then, he does not even list LindsayKauer's edition.

${ }^{17}$ At Hec. 1-2 haec quom datast/nouā, nouom... Goldberg's note ad loc. says 'Enjambment of the first line puts the colon boundary after nouā, allowing its naturally light final syllable to be treated as heavy in the manner characteristic of verse ends', which is metrical nonsense. Cf. n. 13 above.

${ }^{18}$ Hec. 208, 557, 791, 880. Goldberg does not bother to say when this was published (first ed. 1926, reprinted with additions by O. Skutsch 1958) and does not list it in his bibliography.

${ }_{19}$ The hope will be vain, because he does not refer anywhere to W. M. Lindsay's Early Latin Verse (Oxford 1922), where Lindsay explained the principles of his (sometimes mistaken or debatable) phonetic and prosodical interpretations (cf. the preface to the $O C T, \mathrm{p}$. iii). It is astonishing that he does not list it in his bibliography.

${ }^{20}$ Nevertheless Barsby inserted the thin end of a wedge which is driven home by Goldberg. The editorial board of the the Cambridge green-and-yellow Greek and Latin Classics series need to think again about this. 
but not for the longer metres, which have almost always to be split on separate lines, and a good deal more often than in the $O C T$ (inner margins 3.25 inches wide) or Barsby (inner margins 3.5 inches wide). An opportunity has been missed here to help the eye and ear of the reader by printing those long verses which break in the middle or elsewhere with the articulation ... c D / A B... as metrical cola on separate lines.

\section{VI}

So far I have had to be more grumpy than grateful, and it is a relief to praise the notes in the Commentary (pp. 84-201). These are consistently good on the bread-and-butter issues of grammar, older Latin forms, syntax, and so on; points of interpretation are made clearly and economically; the notes have been carefully vetted, and remaining misprints are few ${ }^{21}$. I miss here or in the section on diction some systematic explanation of the way that the hic, iste, ille family of adjectives, pronouns, and adverbs work, both with and without the suffix $-\mathrm{c}(\mathrm{e})$, but these are all efficiently attended to piecemeal as they occur. There is not much attention to the ways that unusual rhythms may contribute almost as stage-directions, for instance in Pamphilus' emotional expressions of regret at Hec. 486-9, where Goldberg has no note ${ }^{22}$, though there are indeed half a dozen good notes on the apt matching of rhythm and sense ${ }^{23}$. There should be more. Given Goldberg's 'thing' about philologists (p. vii, al.), actual textual discussion is thin on the ground (see the notes on lines 201, 620-1).

Each section of the commentary offers first an overall description of what is happening, of who is coming or going and from where and why, of how they look and sound, and of ironies, possible interplay withe audience, and so on. These come to 18 mini-essays corresponding pretty closely to the traditional act and scene divisions ${ }^{24}$. The notes on lines of the play vary from one apt word to about a third of a page; the headnotes for each scene are rarely much longer than that, and are not distinguished typographically, which is a pity, for they are carefully and thoughtfully composed and have the air of a coherent essay or article that has simply been divided into its parts for the present purpose. They work well, and from what Goldstein says in his preface (p. vii), though he does not clearly point to these pieces, he may well think that they are his most important contribution as a 'performance critic' to the study of Terence, preposterous as his pretensions to primacy are. It has to be said that in other respects he has nothing to add to the elucidation of

${ }^{21}$ p. 100 line 4 from bottom, read 191-201 for 109-201; p. 203, line 7 from bottom, read pepererit for perpererit.

${ }^{22}$ cf. $C H C L$ vol. 2, Cambridge 1982, p. 91.

${ }^{23}$ See the notes on Hec. 117, 177, 203, 229, 277, 779.

${ }^{24}$ There is no discussion of these as such, so that the reader may mistakenly think that they go back to Terence. 
the play, though both the brief appendixes on Philumena's pregnancy (pp. 203-4) and 'Greek Analogues' (pp. 205-8) are also good.

\section{VII}

The bibliography (pp. 209-20) lists nearly 300 items. The commentaries by Carney (1963) and Ireland (1990) are acknowledged and included, but it is odd to see Barsby's Loeb edition (2001), little used anyway, only cited alongside four standard Latin grammatical works and one Greek edition of Menander in a list of abbreviations on p. ix, none of which are in the main bibliography. A few startling omissions have been mentioned above, and they are not the only ones, e.g. Questa's La metrica di Plauto e di Terenzio, Urbino, 2007. Perhaps the most striking feature of the list is that as many as 89 items, that is $30 \%$, are dated 2000 or later, and only 34 , that is $11 \%$, date from before 1960. Time will tell whether that is a good or a bad thing. Overall $248(83 \%)$ are in English; 27 are in German, 14 in Italian and 9 in French. The topical index (pp. 221-3) has 120 lemmata and, though usefully various, is skimpy compared with Barsby's 301 entries and with their thoroughness.

\section{CONCLUSION}

The Goldberg variations? Certainly a very mixed bag, offering short measure and sloppinees in matters that do not particularly interest Goldberg, and flaws of organization and presentation in the Introduction. The shameless adoption of an out-of-date standard text is frankly a disgrace to the series, but the editorial board is perhaps more at fault here than the commentator. On the other hand, the headnotes and the notes in the commentary are excellent. One wonders whether it was ever an option to locate the whole of this producer's-eye narrative as a continuous account in the Introduction, for as it is, it may attract less attention from students than its coherence deserves, and it would have incidentally clarified the structure and coherence of the whole Introduction. It could serve equally well as the self-sufficient commentary for any English translation of the play. As it is, this Hecyra in all respects other than in its notes falls short in quality set alongside Barsby's Eunuch.

A. S. GRATWICK

University of St. Andrews asg1@st-andrews.ac.uk 
